\title{
Antecedents and Outcomes of Corporate Reputation Customer-based Analysis
}

\author{
MUHAMMAD TUFAIL \\ Assistant Professor, Institute of Business Studies and Leadership \\ Abdul Wali Khan University Mardan \\ tuphail@yahoo.com \\ AMIR ISHAQUE \\ Lecturer, National University of Modern Languages, Peshawar Campus \\ MUHAMMAD IRFAN \\ Lecturer, National University of Modern Languages, Peshawar Campus
}

\begin{abstract}
For any organization its image and reputation is the level of affectionateness in the minds of employees, customers, expected candidates, and competitors, Reputation is the most critical and strategic asset that a corporation possess (Cravens et al., 2003). The objectives of the study was to examine the antecedents and outcomes of corporate reputation. The study was quantitative in nature. Data were collected by using convenient sampling technique from twin cities (i.e. Islamabad and Rawalpindi) of Pakistan. Respondents were asked to answer the questions keeping in mind the mobile company whose connection they use frequently or on permanent basis. Simple correlation and regression methods were used for analysis of data. Results revealed that if a customer is satisfied with the products and services offered by the company than the reputation of the company in the eyes of the customer will increase. In the same way, when customer has trust on the services offered by the company his confidence level will increase on the future offers and service quality of company resulting an increase in the reputation of the firm and this company reputation will influence customer loyalty and positive word of mouth. Managerial implications and recommendations for future research are given at the end.
\end{abstract}

Key Words: Corporate reputation, Antecedents, Customer loyalty

\section{Introduction}

Corporations are judged by their image in the market. Corporate reputation is decisive when understood by various stakeholders due to the reason that it cut the routine costs and affect economic and customer related display like customer satisfaction, level of confidence, trust and loyalty (Kreps and Wilson 1982; Shapiro 1983; Williamson 1985; Dowling 2001; Roberts and Dowling 2002; Rose and Thomsen 2004). Corporate reputation is the most critical portion for higher performance of the firm (Kay, 1993). 
Corporations with improved reputation have lead upon their competitors. Wang et al. (1999) suggests reputation is treated as publics' information about a company in their long-term memory. The main aspect regarding the reputation is not something which is affirmed by the management but what the outsiders think it to be alike.

For any organization its image and reputation is how affectionate it is in the minds of employees, customers, stake holders, expected candidates, and competitors, reputation is the most critical and strategic assest that a corporation possess (Cravens et al., 2003). In order to manage the organization's reputation public relations departments exist in the organizations. Corporate identity, image and reputation are used interchangeably. Identity is the perception of insider of the firm i.e. employees and managers and image is the perception of outside observer. Reputation is the aggregate result of these two perceptions (Barnett et al, 2006). The present study only deals with one of the external observer i.e. customers. Corporation reputation has largely been studied with reference to the multiple stakeholder but the present study focuses on the customer based corporate reputation. Customers are the main source of income and it is very important to know how customers understand the corporate reputation, what are the determinants of corporate reputation from customers perspective and what are the outcomes of reputation, how it effects the customer behavior and generates the loyalty of the customer. The positive word of mouth has strong effect for the reputation of the firm. Sometimes, positive word of mouth has stronger effect than the powerful marketing campaigns.

\subsection{Objectives of the Study}

Objectives of the study were to examine the antecedents and outcomes of corporate reputation. This may help organizations and policy makers to understand the concept of corporate reputation and ways to build positive image of their organization in the minds of their customers.

\section{Literature Review}

Literature on the corporate reputation presents the measures of corporate fame as financial interpretation, social responsibility and consistency of the services. Most of the work done on the subject deal with the financial aspect of corporate dimension. Previous studies have mainly focused on multiple stakeholder group and customer focused studies are less common (Doney and Cannon, 1997). As a result, studies focused on the corporate reputation antecedents which are not connected with customers Dowling (2001) argued that an important determinant of corporate reputation is the affiliation an individual maintains with the organization and customers than other stakeholders are willing to continue link and relationship with the company. He further argued that the reputation is the sum total of esteem, respect, belief and assurance of the upcoming events of the company. According to Walsh and Beatty (2007) the corporate reputation is the result of the overall assessment of a company. In the same direction Gotsi and Wilson (2001) suggested that the corporate repute is a stakeholder's valuation of a company over the time, based on the direct practices with the organization and some other shape of communication that gives information about the firm's action and compassion with the actions of other leading rivals. 
Nguyan and Leblanc (2001) elaborated that the corporate reputation has a positive outcomes on customer loyalty towards firm. Their study reveals that the degree of customer loyalty tends to be higher when perception of corporate reputation is strongly favorable. Their study also focuses on the customer retention due to the increased customer loyalty. Argenti and Druckenmiller (2003) argued that the companies gradually identify the significance of corporate reputation to attain business goals and keep on the competition. In modern years, companies cultured determined modules regarding how fast a dented reputation can damage employee and loyalty of the customer. Trust means advocating for the customer's long-term interests. It is hard to earn trust but very easy to lose, but once the company when a company achieves it, there are continual reimbursements (Urban, 2003).

\subsection{Antecedents of Corporate Reputation}

\subsubsection{Customer satisfaction}

Customer satisfaction was addressed by Cardozo (1965) for the first time and said that customer satisfaction results in increasing the buying behavior. Olive (1997) stated that customer satisfaction is an emotional response a person shows after any precise business or transaction. As the due to difference in individuals and buying behavior it is a bit difficult to gauge that which specific product or services will give the maximum satisfaction to the customer (Maiyaki et al., 2011). In the same context Shapiro (1983) suggested that customer is one of the important stakeholders in enhancing the reputation of any corporation. Walsh et al (2006) found that there is significant relationship between corporate reputation and customer satisfaction. The same result was confirmed by Helm et al (2010). In the light of above discussion it is likely that a customer will assign good reputation to a company which accomplish or exceed their prospects.

\section{$H_{1}: \quad$ Customer satisfaction has a positive effect on customer-based corporate}

\subsubsection{Trust} reputation.

According to Morgan \& Hunt (1994) trust is the assurance that one party has on another due to trustworthiness and integrity. According to Doney \& Cannon (1997) trust is shaped of two dimensions: perceived credibility and benevolence. Credibility refers to the reliability, honesty of other party, while the second dimension is related to the fair objectives to meet the demands and needs of the other partner. Studies have elaborated that reputation has an impact on the degree customer's trust (Lee, 2005; Lacy, 2007)

$\mathrm{H}_{2}$ : Trust has a positive effect on customer-based corporate reputation.

\subsection{Corporate Reputation}

The idea of corporate has been rooted from corporate image in 1950's and then developed into corporate identity in decades of 1970 and 1980 (Bennett \& Kottasz, 2000). In the same vein Fombrun (1996) stated that the reputation is based on the sum of collective beliefs regarding the aptitude and eagerness to comply the interests of stakeholders of any company. Similarly Bromley (2002) and Sandberg (2002) believed that reputation is a socially shared image and an agreement that how a firm will react in any particular situation. Regarding the benefits Gray and Balmer (1998) elaborated that 
in the current dynamic environment the survival of any firm depends upon structure and sustaining a better corporate reputation. According to Walsh et al (2008) four dimensions encompasses the corporate reputation including customer orientation, excellent employer, trustworthy and financial good company and lastly the product and service quality. Customer orientation is related to the perception of the customer that the company satisfies the customer needs, excellent employer refers to the concept that how fairly the company treats its employees and gives the considerable interest to their needs and interests and the company is having excellent employees, the third dimension is related to company's overall financial position and competence. The last dimension is related to the quality of services the company provides to the customers.

\subsection{Outcomes of Corporate Reputation}

\subsubsection{Customer Loyalty}

Customer loyalty is the surety of customer to buy any particular products or services of a specific organization over a constant time period regardless of the innovative products and services of its competitors and these consumers are not willing to switch (Oliver, 1997). It is like to maintain the long term affiliation between customer and organization. (Gundlach, Achrol \& Mentzer, 1995; Anderson \& Weits, 1992). Dick \& Basu (1994) stated that customer loyalty is the potency of the attitude towards the object relatively available alternatives. Shapiro (1983) stated that ideal corporate reputation results in elevated market share and financial performance of the firm. Research studies like Porter (1985), Robertson (1993) stated that first class reputation aids firm's to build strengthen association with customers. In the same direction Nguyen \& Leblanc (2001) found that the level and degree of the loyalty of customer is professed to be higher when customer is imaging strong and fair perception about the corporate reputation.

$H_{3}$ : $\quad$ Customer-based corporate reputation has a positive effect on customer loyalty.

\subsubsection{Word of mouth behaviour}

According to Chaudhri and Holbrook (2001) the customers who trust any product will show positive attitude, will pay a premium price, will be loyal to that product and finally results in positive word of mouth.

A satisfied customer will spread a postive word of mouth and company will not pay for that to him.

$H_{4}$ : Customer-based corporate reputation has a positive effect on customers' positive word of mouth. 


\subsection{Conceptual Framework}

The conceptual framework encompasses the cusomter variables that influence the customer based corporate reputation. The conceptual model includes the two antecedents and two consequences of customer based coporate reputation.

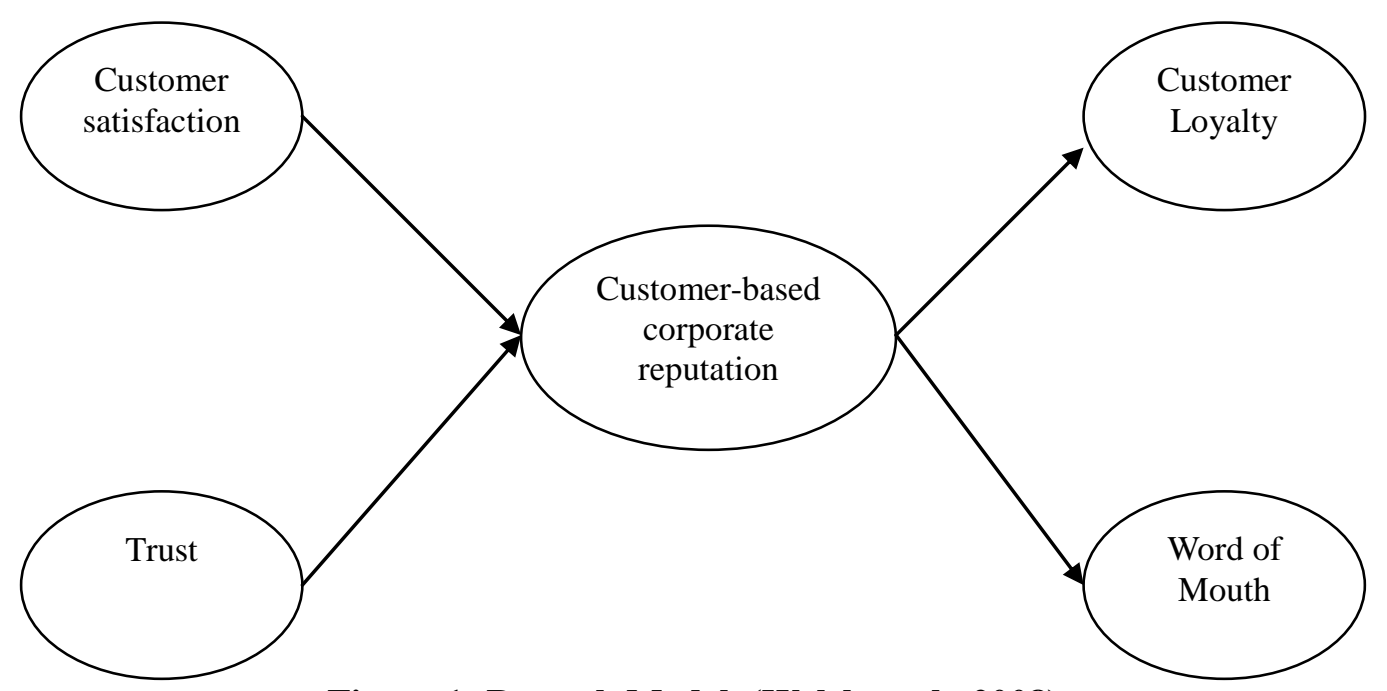

Figure 1: Reserch Model (Walsh et al., 2008)

\section{Dependent \& Independent Variables and Equations:}

1. Customer-based corporate reputation $=$ Customer satisfaction + Trust

$$
C R=\alpha+\beta_{1} C S+\beta_{2} \text { Trust }+\mu
$$

2. Customer loyalty $=$ Customer-based corporate reputation

$$
\text { Loyalty }=\alpha+\beta_{1} C R+\mu
$$

3. Word of mouth $=$ Customer-based corporate reputation

$$
W O M=\alpha+\beta_{1} C R+\mu
$$

\section{Research Design and Methodology}

The study was quantitative in nature. Data was collected from twin cities (i.e. Islamabad and Rawalpindi) of Pakistan. Convenient sampling method was used. A total of 243 questionnaires were distributed, out of which 210 questionnaires were returned by the respondents. After careful scrutiny of received questionnaires, 33 questionnaires were found incomplete or wrongly filled making them invalid for further analysis. Respondents were asked to answer the questions keeping in mind the mobile company whose connection they use frequently or on permanent basis. The questionnaire was adopted from Walsh et al. (2008) with modification according to our business environment. The questionnaire was having questions related to the corporate reputation dimensions and antecedents and outcomes of corporate reputation. There were total of 12 questions addressing four dimensions of corporate reputation. Antecedent variable part 
was having total of 7 questions, three questions addressing customer satisfaction, four questions for trust variable. Outcomes variable part was having total of 5 questions, three for loyalty and 2 for word of mouth measurement. In addition, research model used by Walsh et al. (2008) was also adopted for the research in hand. Customers were asked to answer the questions on 5 point Likert scale having options from strongly agree to strongly disagree where 1 stands for strongly agree and 5 for strongly disagree. Afterwards, pre-testing of questionnaire was done by distributing the questionnaire to 20 respondents. Respondents were closely observed at the time of pre-testing. Some of the shortcomings/confusing questions were indicated by the respondents during pre-testing that were removed. Respondents include male and female within the age bracket of 20 to 50 years including professional and non professional respondents. Data was collected from the $2 \mathrm{x}$ markets of Rawalpindi i.e. Saddar and Commercial market satellite town and 2 x markets of Islamabad i.e. Karachi company, G-9 Market and Jinnah super, F-7 Market.

\section{Data Analysis}

The data was analyzed using SPSS 20.0. Reliability analysis, descriptive statistics, correlation analysis and regression analysis were performed to prove the hypothesis. Cronbach's alpha was calculated for reliability analysis of the construct and was found at $81.9 \%$.

Table 4.1: Descriptive Statistics

\begin{tabular}{|lccc|}
\hline & $\mathrm{N}$ & Mean & Std. Deviation \\
\hline $\mathrm{CR}$ & 210 & 2.2172 & .44675 \\
$\mathrm{CS}$ & 210 & 2.1873 & .73067 \\
Trust & 210 & 2.2988 & .59226 \\
Loyalty & 210 & 2.2155 & .61719 \\
WOM & 210 & 2.3548 & .82084 \\
Valid N (listwise) & 210 & & \\
\hline
\end{tabular}

Descriptive statistics shows the highest values of mean is 2.3548 and minimum value is 2.1873 . Means values are very close to each other for all variables and remain close to 2. Highest value for standard deviation is 0.8208 and lowest value is 0.44675 . 
Table 4.2: Correlations

\begin{tabular}{|c|c|c|c|c|c|}
\hline & CR & CS & Trust & Loyalty & WOM \\
\hline CR & 1 & & & & \\
\hline \multirow[t]{2}{*}{$\mathrm{CS}$} & $.530(* *)$ & 1 & & & \\
\hline & .000 & & & & \\
\hline \multirow{2}{*}{ Trust } & $.636(* *)$ & $.376(* *)$ & 1 & & \\
\hline & .000 & .000 & & & \\
\hline \multirow[t]{2}{*}{ Loyalty } & $.678(* *)$ & $.698(* *)$ & $.619(* *)$ & 1 & \\
\hline & .000 & .000 & .000 & & \\
\hline \multirow[t]{2}{*}{ WOM } & $.473(* *)$ & $.342(* *)$ & $.380(* *)$ & $.468(* *)$ & 1 \\
\hline & .000 & .000 & .000 & .000 & \\
\hline
\end{tabular}

** Correlation is significant at the 0.01 level (2-tailed).

Correlation matrix shows the relationship of the variables with each other. All the independent variables ie CS (Customer Satisfaction), Trust, loyalty and WOM (Word of Mouth) are highly correlated with dependent variable CR (Corporate Reputation) and significant at 0.01 level. Independent variables are also positively correlated with each other. Loyalty is highly positively correlated with CS and Trust. WOM is also positively correlated with other three independent variable ie CS, Trust and loyalty. The maximum value for correlation coefficient is 0.698 and the lowest coefficient of correlation is 0.342 . All the coefficients are below then the 0.7 which shows that there is no multicollinearity in the variables. The matrix shows that all variables are related and have effect on each other and suitable for the regression test.

\section{Table 4.3: Antecedents of Corporate Reputation} $\left(C R=\alpha+\beta_{1} C S+\beta_{2}\right.$ Trust $\left.+\mu\right)$

\begin{tabular}{|lcccccc|}
\hline Variables & $\mathbf{R}^{2}$ & Adjusted $\mathbf{R}^{2}$ & F Statistics & B & t & Sig. $(\mathbf{F})$ \\
\hline CS &. .502 & .498 & 104.520 & .338 & 6.109 & .000 \\
Trust & & & & .508 & 9.608 & \\
\hline
\end{tabular}

Regression analysis of first model which has the depdendent variable corporate reputation and two independent variables Trust and Customer Satisfaction (CS). The 1 
results show the values of coefficient of determination $R^{2}$ is 0.502 which explains that the independent variables Trust and CS defines the corporate reputation upto approximately $50 \%$. Remaining 50\% are the other variables. As we have discussed in our study only two customer related variables were used. 't' value for CS is 6.301 and for Trust is 9.608. P values are less than 0.05 (95\% confidence level) which shows that the values are significant and Customer satisfaction and Trust has significant impact on the Corporate Reputation.

Table 4.4: Outcomes of Corporate Reputation $\left(\right.$ Loyalty $\left.=\alpha+\beta_{1} C R+\mu\right)$

\begin{tabular}{|lcccccc|}
\hline Variable & $\mathbf{R}^{2}$ & Adjusted $\mathbf{R}^{2}$ & F Statistics & $\boldsymbol{\beta}$ & $\mathbf{t}$ & Sig. (F) \\
\hline Loyalty & .460 & .457 & 177.000 & .678 & 13.304 & .000 \\
\hline
\end{tabular}

Regression analysis of second model which has the dependent variable loyalty and one independent variables Corporate Reputation. The results show the values of coefficient of determination $\mathrm{R}^{2}$ is 0.460 which explains that the independent variable Corporate Reputation effects the loyalty upto approximately $46 \%$. Remaining 54\% are the other variables. ' $\mathrm{t}$ ' value for Corporate Reputation is 13.304 . $\mathrm{P}$ value is less than 0.05 (95\% confidence level) which shows that the values are significant and Corporate Reputation has significant effect on the Customer Loyalty (CS).

Table 4.5: $\left(\mathrm{WOM}=\alpha+\beta_{1} \mathrm{CR}+\mu\right)$

\begin{tabular}{|lcccccc|}
\hline Variables & $\mathbf{R}^{2}$ & Adjusted R $^{2}$ & F Statistics & $\boldsymbol{\beta}$ & $\mathbf{t}$ & Sig. (F) \\
\hline WOM & .223 & .220 & 59.794 & .473 & 7.733 & .000 \\
\hline
\end{tabular}

Regression analysis of third model which has the depdendent Word of Mouth (WOM) and one indepdent variables Corporate Reputation. The results show the values of coefficient of determination $\mathrm{R}^{2}$ is 0.223 which explains that the independent variable Corporate Reputation effects dependent variable WOM upto approximately $22 \%$. Remaining $78 \%$ are the other variables. ' $\mathrm{t}$ ' value for Corporate Reputation is 7.733. $\mathrm{P}$ values are less than 0.05 (95\% confidence level) which shows that the values are significant and Corproate Reputation has significant effect on the positive Word of Mouth (WOM). 


\section{Conclusion}

Correlation matrix proves the positive relations of the variables with corporate reputation and among each other. All three regression model produced the significant results which shows that the Antecedent of the corporate reputation i.e. Customer Satisfaction and Trust are significant with Corporate Reputation. So we can conclude that if customer is satisfied with the products and services offered by the company than the reputation of the company in the eyes of the customer will increase. Same is the case with Trust variable. When customer has trust on the services by the company then it will increase confidence level of the customer on the company that the future offers and service quality of company will be the same or even improved consequently the reputation of the firm will be increased. While outcomes of the corporate reputation ie Customer loyalty and WOM also have significant relationship with the Corporate Reputation. When the company has good reputation in the minds of the customer then customer loyalty will be increased. Customers have a general behavior of looking for the products and services of the good reputed companies. It is due to the fact that good reputed companies care more for the customers and are reliable. Moreover another outcome of the reputation is the positive Word of Mouth which is very influential. Positive word of mouth affects the potential customer more than the advertising / marketing efforts of the company.

\begin{tabular}{|clc|}
\hline S.No & \multicolumn{1}{c|}{ Hypothesis } & Status \\
\hline 1. & $\begin{array}{l}\text { Customer satisfaction has a positive effect on customer- } \\
\text { based corporate reputation }\end{array}$ & Accepted \\
2. & $\begin{array}{l}\text { Trust has a positive effect on customer-based corporate } \\
\text { reputation. }\end{array}$ & Accepted \\
3, & $\begin{array}{l}\text { Customer-based corporate reputation has a positive effect } \\
\text { on customer loyalty. }\end{array}$ & Accepted \\
4. & $\begin{array}{l}\text { Customer-based corporate reputation has a positive effect } \\
\text { on customers' positive word of mouth. }\end{array}$ & Accepted \\
\hline
\end{tabular}

\subsection{Managerial Implications}

There is lot stuff for the Managers to pay attention to. Common wisdom suggests that attending to the corporate reputation makes good business sense. Customer based corporate reputation is not only influenced by, but also influences important customer behavior related variables. The finding suggests that the delivering customer satisfaction can be very helpful in achieving their goals. When customers are satisfied they give more weightage to the elements of reputation. Another implication for the service firm is that the customer satisfaction and trust influencing customer based corporate reputation is built by the interaction of the customer with the employees of the company. So the employees should be empowered and necessary trainings should also be provided to them to deal with the customer and solve their problems. The results further suggest that the good reputation increases customer's loyalty and thus the retention of the customer. In addition to that the positive word of mouth which has the promotional effect. 


\subsection{Further Research}

The present study contributes to existing literature on important issue of management science that is corporate reputation for Pakistan which is developing market. It has its own business environment and customer requirement and we try to modify the study according to the needs of our country. There are several aspects which can be explored in future research in this area. First, we can expand our sample and include other cities. In investigating the determinants of corporate reputation we can look upon other factors that influence corporate reputation, for example after sale service, expenditure on research and development and quality control etc. From methodological point of view more sophisticated techniques can be used such as oblique factor analysis. In addition the analysis of corporation perception about corporate reputation would add both side of the picture.

\section{References}

Anderson, E., \& Weitz, B. (1992). The use of pledges to build and sustain commitment in distribution channels. Journal of marketing research, 18-34.

Argent, P.A., \& Druckenmiller, B. (2004). Reputation and the Corporate Brand. Corporate Reputation Review, 6, 368-374.

Barnett, M. L., Jermier, J. M., \& Lafferty, B. A. (2006). Corporate reputation: The definitional landscape. Corporate reputation review, 9(1), 26-38.

Bennett, R. \& Kottasz, R. (2000). Practitioners perceptions of corporate reputation: An empirical investigation, Corporate Communications. An International Journal, 5(4):224-234.

Bromley, D. B. (2002). Comparing corporate reputations: League tables, quotients, benchmarks, or case studies. Corporate Reputation Review, 5:35-50.

Cardozo, R. N. (1965). An experimental study of customer effort, expectation, and satisfaction. Journal of marketing research, 244-249.

Chaudhuri, A., \& Holbrook, M. B. (2001). The chain of effects from brand trust and brand affect to brand performance: the role of brand loyalty. The Journal of Marketing, 81-93.

Cravens, K., Oliver, E. G., \& Ramamoorti, S. (2003). The Reputation Index: Measuring and Managing Corporate Reputation. European Management Journal, 21(2), 201-212.

Doney, P. M., \& Cannon, J. P. (1997). An examination of the nature of trust in buyerseller relationships. the Journal of Marketing, 35-51.

Dowling, C., Bollen, A. W., Noworolski, S. M., McDermott, M. W., Barbaro, N. M., Day, M. R., ... \& Vigneron, D. B. (2001). Preoperative proton MR spectroscopic imaging of brain tumors: correlation with histopathologic analysis of resection specimens. American journal of neuroradiology, 22(4), 604-612.

Dowling, G. (2001). Creating corporate reputations: Identity, image and performance. Oxford: Oxford University Press.

Dick, A., Basu, K. (1994). Customer loyalty: toward an integrated conceptual framework. Journal of the Academy of Marketing Science, 22 (2): 99-113. 
Fombrun, C. (1996) Reputation, Harvard Business School Press, Boston.

Gotsi, M., \& Wilson, A. M. (2001). Corporate reputation: seeking a definition.Corporate Communications: An International Journal, 6(1), 24-30.

Graay, E.R. \&Balmer, J.M.T. (1998). Managing corporate image and corporate reputation. Long Range Planning, 31(5):695-702.

Gundlach, G. T., Achrol, R. S., \& Mentzer, J. T. (1995). The structure of commitment in exchange. The Journal of Marketing, 78-92.

Helm, S., Eggert, A. \& Garnefeld, I. (2010). Modeling the impact of corporate reputation on customer satisfaction and loyalty using Partial Least Squares. Handbook of Partial Least Squares, Part 2, 515-534.

Kay, J. (1993). Foundations of corporate success. Oxford: Oxford University Press.

Kreps, D. M., \& Wilson, R. (1982). Reputation and imperfect information. Journal of Economic Theory, 27(2):253 -279.

Lacey, R. (2007). Relationship drivers of customer commitment. The Journal of Marketing Theory and Practice, 15(4), 315-333.

Lee, B. K. (2005). Hong Kong consumers' evaluation in an airline crash: A path model analysis. Journal of Public Relations Research, 17(4), 363-391.

Maiyaki, A.A., Noor, N.B. \& Mokhtar, S.S. (2011). The influence of service quality of mobile phone on customer satisfaction in Malaysia: A students' feedback survey. Journal of Business, Management and Account, 1(1): 79-97.

Morgan, R. M. \& Hunt, S. (1999). Relationship-based competitive advantage: the role of relationship marketing in marketing strategy. Journal of Business Research, 46(3), 281- 290

Nguyen, N., \& Leblanc, G. (2001). Corporate image and corporate reputation in customers' retention decisions in services. Journal of retailing and Consumer Services, 8(4), 227-236.

Oliver, R. (1997). Satisfaction: a behavioral perspective on the consumer. New York, McGraw Hill.

Porter, M. (1985). Competitive Advantage: Creating and Sustaining Superior Performance. The Free Press, New York.

Sandberg, K. (2002). Kicking the tires of corporate reputation. Harvard Management Communication Letter, 5:3-4.

Shapiro, C. (1983). Premium for high quality products as returns to reputations. Quarterly Journal of Economics, 98(4):659-679.

Roberts, P. W. \& Dowling, G. R. (2002). Corporate reputation and sustained superior financial performance. Strategic Management Journal, 23(12): 10771093.

Robertson, T.S. (1993). How to reduce market penetration cycle times. Sloan Management Review, 35 (1): 87-96.

Rose, C. \& Thomsen, S. (2004). The impact of corporate reputation on performance: Some Danish evidence. European Management Journal, 22(2):201-210. 
Urban, J. P. \& Roberts, S. (2003). Degeneration of the intervertebral disc.Arthritis Research and Therapy, 5(3), 120-138.

Walsh, G., \& Beatty, S. E. (2007). Customer-based corporate reputation of a service firm: scale development and validation. Journal of the Academy of Marketing Science, 35(1), 127-143.

Walsh, T. J., Anaissie, E. J., Denning, D. W., Herbrecht, R., Kontoyiannis, D. P., Marr, K. A., ... \& Patterson, T. F. (2008). Treatment of aspergillosis: clinical practice guidelines of the Infectious Diseases Society of America. Clinical infectious diseases, 46(3), 327-360.

Walsh, G. Dinnie, K. \& Wiedmann, K.P. (2006). How do corporate reputation and customer satisfaction impact customer defection? A study of private energy customers in Germany. Journal of Services Marketing, 20(6):412 - 420.

Wang, Z., Yu, G., Cascio, C., Liu, Y., Gingrich, B., \& Insel, T. R. (1999). Dopamine D2 receptor-mediated regulation of partner preferences in female prairie voles (Microtus ochrogaster): a mechanism for pair bonding?. Behavioral neuroscience, 113(3), 602 .

Williamson, O. E. (1985). The economic institutions of capitalism and firms, markets and relationship contracting. New York: Free Press. 
